\title{
LXXVIII. Observations on the crystalline form sillimanite
}

\section{W. Phillips F.L.S. G.S.}

To cite this article: W. Phillips F.L.S. G.S. (1827) LXXVIII. Observations on the crystalline form sillimanite, Philosophical Magazine Series 2, 1:6, 401-402, DOI: 10.1080/14786442708674350

To link to this article: http://dx.doi.org/10.1080/14786442708674350

曲 Published online: 10 Jul 2009.

Submit your article to this journal ๘

Џ Article views: 3

Q View related articles $\sqsubset$ 
THE

\title{
PHILOSOPHICAL MAGAZINE
}

\author{
$A N D$ \\ ANNALS OF PHILOSOPHY. \\ [NEW SERIES.] \\ $J U N E 1827$.
}

\section{Observations on the Crystalline Form of Sillimanite. By W. Phillitrs, F.L.S. G.S. \& . $^{*}$ *}

THIS mineral was first described by Bowen in the American Journal of Science for May 1824, and is therein said to occur in rhomboidal prisms of about $106^{\circ} 30^{\prime}$ and $73^{\circ} 30^{\prime}$, the inclination of the base on the axis of the prism being $113^{\circ}$; and as having one cleavage parallel to the longest diagonal of the prism. In the translation by Haidinger, of Mohs's System, \&c. the measurements quoted are the same as those given by Bowen.

This mineral being always found, I believe, imbedded, and chiefly in quartz, its prisms are frequently somewhat bent, sometimes even twisted; and their planes being generally far from bright, and occasionally somewhat convex, are mostly unfit for accurate measurement. Having attempted to measure several by means of the reflective goniometer, I was unable to find any one affording the measurements above mentioned; but almost uniformly found the prism bounded by several longitudinal planes, of which however it was difficult to obtain the measurements, for the reasons already stated. At length I succeeded in detaching from the matrix some very thin prisms presenting but four lateral planes, which afforded constantly angles of about $88^{\circ}$ and $92^{\circ}$; but they were far from bright: these slender prisms are nearly transparent and colourless, or have only a slight tinge of yellow; and at first some doubt arose whether they were in reality prisms of sillimanite. They agreed with it in being very hard; but it occurred to me that if I could procure the easy and brilliant

* Communicated by the Author.

Nerv Series. Vol. 1. No. 6. June 182\%. $3 \mathrm{~F}$ plane 
plane of cleavage parallel to one of the diagonals of the prism, it would satisfactorily prove them to be that substance: and the attempt succeeded; but I found it to be parallel to the shortest diagonal of the prism.

Again, taking advantage of this cleavage, I obtained it on some of the larger prisms having several lateral planes: it is represented by $f$ on the second of the following figures; and the measurements accompanying the figures were afterwards obtained.
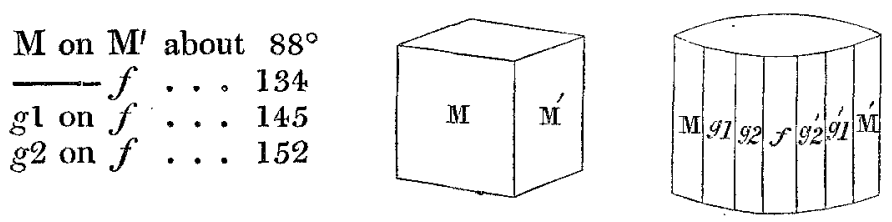

From the foregoing circumstances I am led to believe, that a rhombic prism of $88^{\circ}$ and $92^{\circ}$ may, in default of better evidence, be adopted as the primary form of this mineral : the planes of this prism are brighter than the other planes. The terminations of the prism are, according to Bowen, oblique to the axis; but 1 have not succeeded in my attempts to find any indications of cleavage in that direction, nor at right an-. gles to the axis. The crystals, indeed, are often separable with ease nearly in that direction, owing apparently to natural fissures across it; but the surfaces produced by the fracture are neither even nor brilliant, nor at a constant angle with the axis. Besides the brilliant cleavage already mentioned, imperfect indications of another at right angles to it may sometimes be observed.

From the close agreement in the analysis of this mineral with that of kyanite, and the measurements adopted by $M$. Haidinger, as may be assumed from Bowen, which also agree very nearly with those of that mineral, he is of opinion that sillimanite is probably a variety of kyanite; an opinion which it is probable will at least receive a revision, on taking into consideration the circumstances above detailed relating to form, measurement and cleavage, in all which the two minerals seem to disagree very decidedly. 